\title{
Transient Analysis of Stochastic Process in Gene Regulation.
}

\author{
H, Hirayama., N, Kitagawa., *Y, Okita and ${ }^{* * T}$, Kazui \\ Asahikawa Merical College hirayama@asahikawa-med.ac.jp \\ *Shizuoka University. **Hamamatsu Medical university.
}

\begin{abstract}
We propose a mathematical method to analyze the transient change in the probability of gene regulation protein particle (a repressor protein ) for the first time arrival at the target operator gene region of the DNA chain. The differential equation for the probabilistic behavior of the repressor molecular particle was diffusion type. The probability was expressed by the modified Bessel functions. By applying the Allen's approximation for the modified Bessel function, we obtained an approximation form of the first time arrival probability of the gene regulation protein particle immediately after the onset of the reaction. The impulse response of the probability showed considerable oscillation. The present result indicates the genctic expression particularly at its initial phase is unstable.

The present method will be available for evaluating the temporal change in the probability of the gene regulation.
\end{abstract}

\section{Introduction.}

Regulation of gene expression on the DNA is one of the most important issue in the life science. Numerous experimental investigations have been reported which lead constructing an entire map of gene. The basic problem, how the gene is regulated particularly at the onset of the gene expression, however, is still in question. Because the lack of rigorous theoretical approach and prediction by simulation approach. The present paper introduce recurrent binding model of the gene regulation protein particle, repressor protein for the target gene region on the DNA ( the operator gene) which has been proposed by Berg ( 1976). In his model, the rate constant of binding reaction of the repressor protein has been calculated and he concluded that the binding reaction can not be explained by a simple diffusional process but may be under the control of the diffusion control. Unfortunately, however, he did not analyze the transient changes in the probability of binding process of the gene regulation protein.

The present paper introduce a mathematical method for analyzing the temporal changes in the binding process of the gene regulation protein immediately after the onset of the binding reaction.

\section{Basic mechanism}

Fig 1( left) shows the whole length $2 \mathrm{~L}$ of the chain with radius $b$ placed along the symmetry axis of a circular cylinder with radius $\mathrm{R}$ including medium. The sink is in the middle of the DNA chain. Irregular line indicates a possible trajectory for the particle before the final absorption. Fig 1 ( right ) shows the double strand of DNA with several base residues.
Fig 1
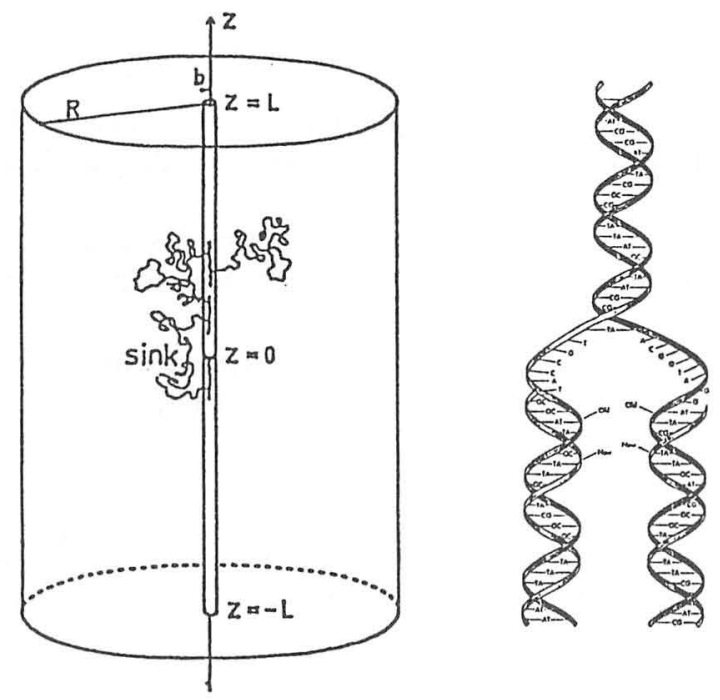

Fig 1. DNA double strands and cylindrical modeling of the probabilistic behavior of the repressor protein around the DNA in the medium.

Fig 2 shows two patterns of gene regulator protein particles. The gene (DNA) is composed of three parts, regulatory region, control region and structural genes. The control region is further consisted of promotor region and operator regions. All of these genes are characterized by their specific arrangements of base residues. The regulator region produces a kind of protein particles named repressor. These particles when they are produced, usually bind to the operator region of the control part. By this linkage, the operator region is frozen to work. As a result, the messenger RNA can not approach to the operator region. Hence, the promotor region of the control gene can not accelerate the transcription of the mRNA. Consequently, the structure gene can not work to produce enzyme or other proteins.

The lower part of Fig 2 shows an activated state of the DNA. When a substrate such that its molecular structure is complemental to that of repressor protein particle, namely inducer binds to the repressor proteins, the inducerrepressor complex can not bind to the operator region any more. As a result, the inhibited operator region is activated to work. As a result, the promotor region can accelerates the transcription of messenger RNA for the structure gene.

Thereforc, the binding and releasing of the repressor particles (here after, we call particle) determine the activity of the gene and its biological system. 


\section{Modeling}

3-1. The basic differential equation

We take an initially homogeneous distribution of particles as repressors and sinks as operators in cylindrical coordinates. Every sink is imbedded in the middle of a long cylindrical chain as a DNA molecule of length $2 \mathrm{~L}$ and radius $\mathrm{b}$. A particle moves with a diffusion constant $\mathrm{D}$ in the medium and every time it faces to the chain, the particle is absorbed into the chain and moves along the chain with the a one dimensional diffusion constant D1.

By the stochastic process for short time duration , dt, with the probability of $\lambda \mathrm{dt}$, the particle will leave the chain unless it has met the sink in which case it would be permanently absorbed.

The diffusional flow of particles into the chain along, off and again onto the chain and finally into the sink is a complicated coupled multiple dimensional diffusion. For the simplicity, we separate the movement of the particle as

$u(z, t) d z$ : The probability that the particles is in the space interval of $(z, z+d z)$ on the chain at the time $t$.

$\mathrm{G}(\mathrm{z}, \mathrm{t}) \mathrm{dz} \mathrm{dt}$ : The probability that a particle for the first time arrivals at the chain in the interval $(z, z+d z)$ in the time interval $(t, t+d t)$

$F\left(z, z^{\prime}, t-t^{\prime}\right) d z d t$ : The probability that a particle leaving the chain from $z^{\prime}$ at time $t^{\prime}$ again returns to the chain in the interval $(\mathrm{z}, \mathrm{z}+\mathrm{dz})$ and in the time interval $(\mathrm{t}, \mathrm{t}+\mathrm{dt})$

For the symmetry reasons, analysis was confined only for the half plane $0<\mathrm{z}<\mathrm{L}$ of the chain. The diffusion equation along the chain becomes

$$
\begin{array}{ll}
\partial u & \partial^{2} u \\
\partial t & \partial z^{2}
\end{array}
$$

The third term describes the return to the chain of a particle that left it at some earlier time. The last term is the arrival of an uncorrelated particle.
3-2. The boundary and initial conditions.

The boundary condition at $\mathrm{z}=0$ for an ideal sink $\mathrm{u}(0, \mathrm{t})=0$

At the ends of the chain the choice of boundary conditions is not crucial and the reflecting boundaries are used

$$
\partial u / \partial z=0 \quad(z= \pm L)
$$

For no initial particle on the chain, the initial conditions are

$$
u(z, 0)=0
$$

The flux of particles into the sink is

$$
\Phi(t)=D 1^{*} \partial \mathrm{u} / \partial \mathrm{z} \quad(\mathrm{z}=0)
$$

Introducing cylindrical coordinates $\mathrm{r}$ and $\mathrm{z}$ with the $\mathrm{z}$ axis along the chain. For symmetry reasons, the angular coordinate does not enter. Assuming that a particle which dissociates from the chain at $z=z^{\prime}$ and time $t=0$ is lifted out the distance $r=a$ from the chain axis to start anew. The mathematical question is

"When and where the particle will return to the chain "

\section{3-3. The method of solution.}

The solution is given by the diffusion equation for the concentration $c(r, z, t)$ of particles

$$
\begin{aligned}
& \partial^{2} \mathrm{c} \quad 1 \quad \partial \mathrm{c} \quad \partial^{2} \mathrm{c} \quad 1 \quad \partial \mathrm{c}
\end{aligned}
$$

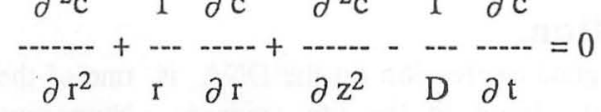

The boundary conditions are

$$
\begin{aligned}
& \partial \mathrm{c} / \partial \mathrm{z}(\text { at } \mathrm{z}=\mathrm{L}, \mathrm{z}=0)=0 \\
& \mathrm{k}^{*} \mathrm{c}(\mathrm{r}=\mathrm{b}, \mathrm{z}, \mathrm{t})-\partial \mathrm{c} / \partial \mathrm{r}(\mathrm{r}=\mathrm{b}, \mathrm{z}, \mathrm{t}) \\
& \partial \mathrm{c} / \partial \mathrm{r}(\mathrm{r}=\mathrm{R})=0
\end{aligned}
$$

and the initial condition

$$
\mathrm{c}(\mathrm{r}, \mathrm{z}, \mathrm{t}=0)=\delta(\mathrm{r}-\mathrm{a}) \delta\left(\mathrm{z}-\mathrm{z}^{\prime}\right) /(2 \mathrm{a} \pi) \cdots
$$

Fig 2
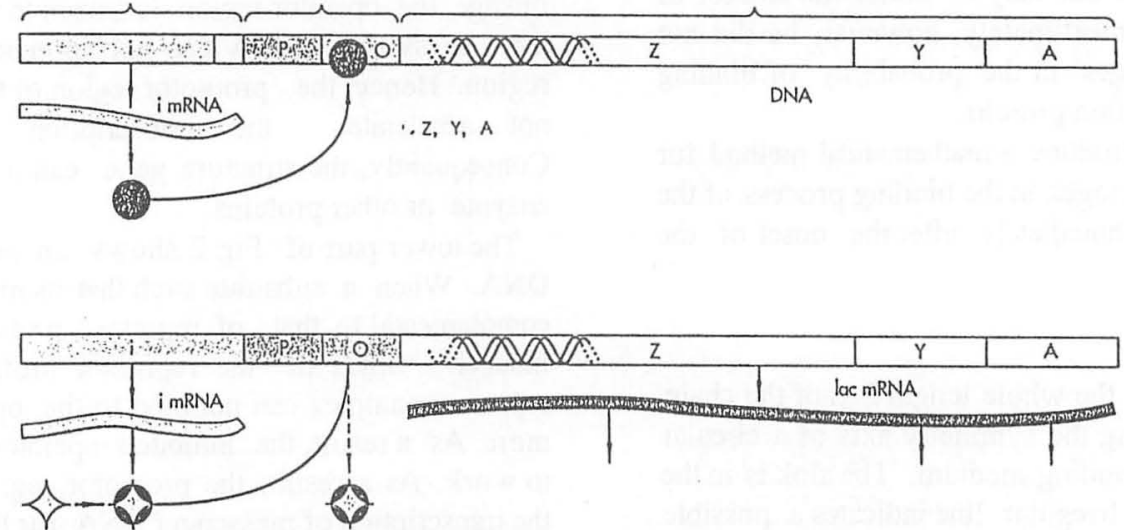

Fig 2 Constitution of the Gene. i is regulator region, $p$ is promotor region, $o$ is operator region. These two regions forms the control region. ZYA are structure genes. The upper figure describes inhibited and lower one activated states. 
$2 \pi$ Dbk would be the association rate onto the chains for a homogeneous distribution of particles.

$$
c(r=b, z, t)=0
$$

The particle flux, $F\left(z, z^{\prime}, t\right)$ back to the chain which enters equation (1) is now given by

$$
\begin{aligned}
\mathrm{F}\left(\mathrm{z}, \mathrm{z}^{\prime}, \mathrm{t}\right) & =2 \pi^{*} \mathrm{~b}^{*} \mathrm{D}^{*} \partial \mathrm{c} / \partial \mathrm{r} \\
& =2 \pi^{*} \mathrm{~b}^{*} \mathrm{D}^{*} \mathrm{k}^{*} \mathrm{c}(\mathrm{r}=\mathrm{b}, \mathrm{z}, \mathrm{t})
\end{aligned}
$$

This can be calculated after solving equation (6) to (12). For the initial conditions, we assume that one particle distributes homogeneously in the cylinder.

$$
C(r, z, t=0)=1 /\left(\pi\left(R^{2}-\frac{12}{2}\right) L\right)
$$

As the solution with (12) is a fundamental solution,

$$
G(z, t)=\int^{L} d z^{\prime} \int^{R} d a 2 \pi a F\left(z, z^{\prime}, t\right) /\left[\pi\left(R^{2}-b^{2}\right) L\right]
$$$$
0 \quad b
$$

The understanding of equation (3-15) is following.

On the homogeneous initial condition (13), the particle start in the distance interval ( $a, a+d a)$ from the chain by the probability $2 \pi \mathrm{a}$ da $/\left(\pi\left(R^{2}-b^{2}\right)\right)$. With the probability $\mathrm{dz} / \mathrm{L}$, the particle will start in the interval $\left(z^{\prime}, z^{\prime}+d z^{\prime}\right)$. Integrating the fundamental solution over all $z^{\prime}$ and a gives the solution G. By using the Laplace tansformation, the solution of equations (6) to (11) is achieved through separating the variables

$$
c(r, z, t)=v(z, t) w(r, t)
$$

The axis ( $\mathrm{z}$ ) dependent part is found to

$$
\begin{aligned}
v(z, t)= & 1 / L+2 / L \sum \cos \left(n \pi z^{\prime} / L\right) \cos (n \pi z / L) \\
& \exp \left(-D t(n \pi / L)^{2}\right)
\end{aligned}
$$

The Laplace form of $\Phi(t)$ of particles into the sink is

$$
\begin{aligned}
& \Phi(\mathrm{s})=\mathrm{L} \mathrm{G}(\mathrm{s}) /\left[1+2 /\{\lambda[1-\phi(\mathrm{s})]+\mathrm{s}\} \sum\left\{\mathrm{D} 1(\mathrm{n} \pi / \mathrm{L})^{2}\right.\right. \\
& \mathrm{n}=1 \\
& \left.\left.+s+\lambda\left[1-\phi\left(s+D n^{2} \pi^{2} / L^{2}\right)\right]\right\}\right]
\end{aligned}
$$

where $\mathrm{q}=\sqrt{ }(\mathrm{s} / \mathrm{D}) . \mathrm{s}$ is Laplace operator. The temporal change of the associated process is determined by the Laplace inverted transform of the $\Phi(\mathrm{s})$.

By expanding the modified Bessel functions on the numerator and denominator by Allen's approximation method,

$$
\mathrm{G}(\mathrm{s})=\sum_{\mathrm{n}=0} N \mathrm{nn} \mathrm{q}^{2 \mathrm{n}} / \sum_{\mathrm{n}=0} \mathrm{Dn} \mathrm{q}^{2 \mathrm{n}}
$$

Fig 3-a

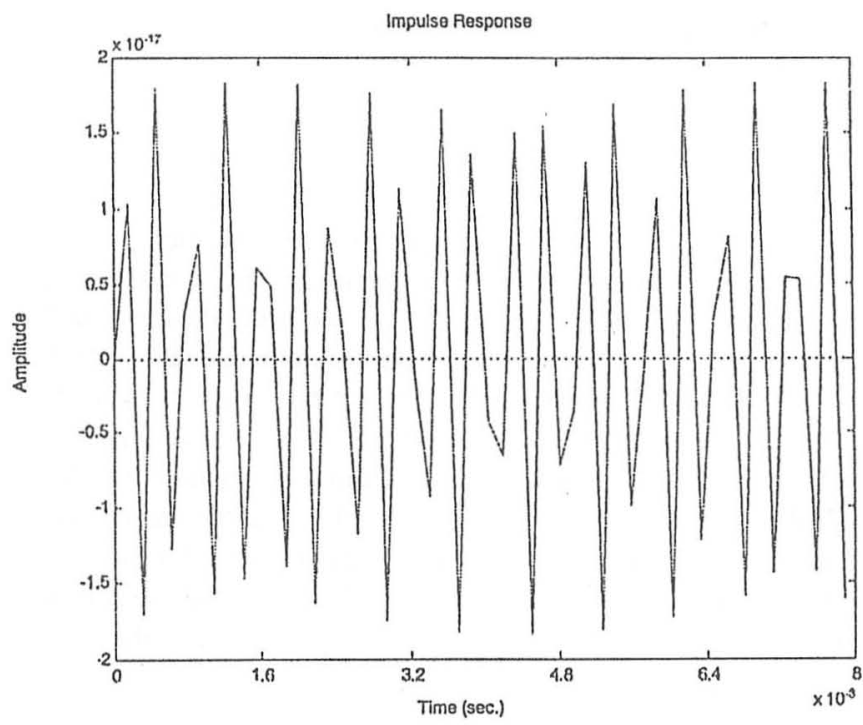

\section{Fig 3-b}

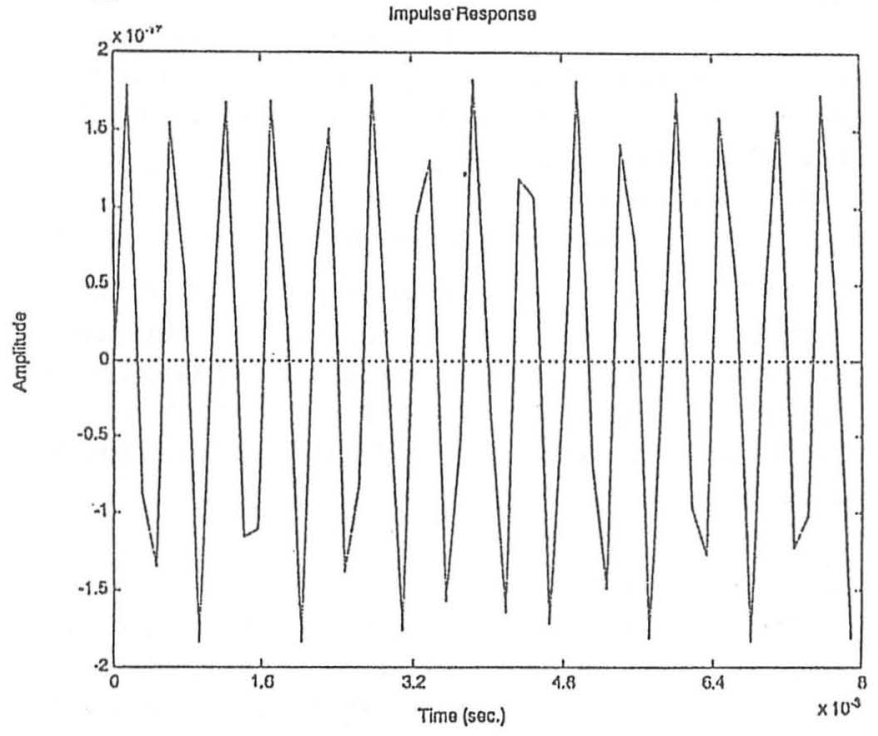

Fig 3. Impulse responses of probability that a particle for the first time arrivals at the chain in the interval $\mathrm{z}$ and $\mathrm{t}$

In summary, the we set following assumptions.

1. A closed cylindrical cell around each chain.

2. Straight chains. As most of the particles dissociating from the chains will be reassociated fats, after small displacements only, they will experience the chains as approximaletly straight. Those straying too far will lose their correlations to the chains.

3. A particle dissociating from the chain is lifted out a distance $a-b$ from the chain where it starts again. There by $a-b$ is introduced as a parameter of the order of one molecular diameter a is approximately twice the $b$. We can let $\mathrm{a}-\rightarrow \mathrm{b}$ and have association governed by the traditional boundary condition (3-10) or let $\mathrm{k}$ infinite and have the association entirely diffusion limited.

4. Only one particle per a sink.

The parameters were

k : microscopic non specify association rate constant $>2 \pi \mathrm{Dl}$ (diffusion control limited) $=10^{3} / \mathrm{M}$ ( F.C. Collins and G E. Kimball 1949) 


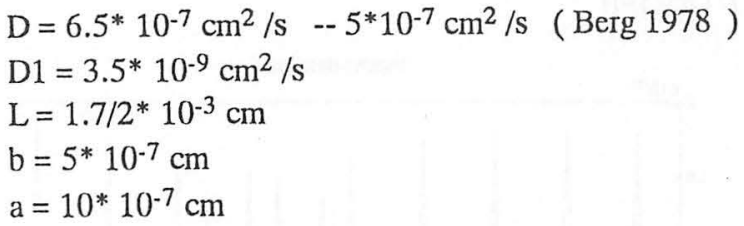

In the APPENDIX, we give important results such as mean time of association $\tau$, the mean time for the first arrival for the DNA chain $\tau 1$, the mean time during which the particle stays outside the chain before being reabsorbed. $\tau 2$. $\quad N \tau 2$ indicates the mean time during which the particle spends off the chains where $\mathrm{N}$ is the mean number of times the particles dissociate from the chain before the final absorption in the sink. $\tau 3=1 / \lambda$ is the mean time during which a particle spends on the chain each time as $\lambda$ is the molecular dissociation rate. $\mathrm{N} \tau 3$ is the total mean time the particle spends on the DNA chain before the final absorption.

\section{Results.}

Fig 3-a shows temporal change in the impulse response of modified probability that a particle for the first time arrivals at the chain in the interval $(z, z+d z)$ in the time interval $(t, t+d t)$, namely

$\mathrm{G}(\mathrm{s}) \mathrm{L}\left(\mathrm{R}^{2}-\mathrm{q}^{2}\right) /(2 \mathrm{bk})$

at $\mathrm{k}=0.0001$. The computation has continued until $\mathrm{t}=$ $8^{*} 10^{-3}$ sec. The impulse response has oscillated significantly with several different frequency components. Fig 3-b shows another case of the transient impulse response at $\mathrm{k}=1$. The amplitude of the oscillation seems to be smooth but still has considerable oscillational change.

\section{Discussion.}

We showed a mathematical method to analyze the transient change of the particle flux $\mathrm{G}(\mathrm{z}, \mathrm{s})$ onto the chain for a particle that has not previously been associated with the chain. The present computation based on the rigorous approximation process for modified Bessel functions. Hence, there may be errors which must have been augmented. The present computation, however, suggested that the regulation of gene expression is not a constant process but would be non linear and gives any oscillatory unstable reaction. Strong comparison with biological experiments will be required to certify the present results.

\section{Conclusion.}

Gene control by repressor particle must be unstable and the impulse response will be oscillative.

\section{Reference.}

1. Berg, O.G. and Blomberg. C. "Association kinetics with coupled diffusional flows. Biophyical . Chemistry. vol 4. pp 367-381. 1976.

2. Collins F C and Kimball G E. J. Colloidal Sci. vol 4. pp 425. 1949.

3. Carslaw H S and Jaegar J C. Conduction of heat in solids ( Oxford Univ. London 1947).
APPENDIX 1-a .

The flux of particle into the sink is

$\Phi(\mathrm{s})=\mathrm{L} \mathrm{G}(\mathrm{s}) /\left[1+2\{\lambda(1-\psi(\mathrm{s}))+\mathrm{s}\}^{*}\right.$

$\left.* \sum 1 /\left\{\mathrm{D} 1(\mathrm{n} \pi / \mathrm{L})^{2}+\mathrm{s}+\lambda\left(1-\psi\left(\mathrm{s}+\mathrm{D}(\mathrm{n} \pi / \mathrm{L})^{2}\right)\right)\right\}\right]$

for $\psi(\mathrm{s}), \mathrm{G}(\mathrm{s})$ where $\mathrm{q}=\operatorname{sqr}(\mathrm{s} / \mathrm{D})$

\section{APPENDIX 1-b. Special values}

The general case of $\mathrm{N}$ particles per sink is, however, also covered by the results through

$$
\Phi N(t)=N \Phi(t) \quad\left(1-\int_{0}^{t} \Phi(t) d t\right)^{N-1}
$$

For the case when a particle can not dissociate from the chain once it has been caught is

$\Phi(\mathrm{s})=\mathrm{L} \mathrm{G}(\mathrm{s}) \tanh \left(\mathrm{L}^{2} \mathrm{~s} / \mathrm{D} 1\right)^{1 / 2} /\left(\mathrm{L}^{2} \mathrm{~s} / \mathrm{D} 1\right)^{1 / 2}-.-(20)$ The mean time can be calculated by taking the derivatives of equation (19) with respect to $s$ and then letting $s-->>0$

$$
\begin{aligned}
\tau & =\tau 1+N \tau 2+\tau \lambda 3 \\
& =R^{2} /(2 D)(\log (R / b)+1 /(b k))+N R^{2} /(2 D) \\
& *(\log (a / b)+1 /(b k))+N / \lambda
\end{aligned}
$$

where

$$
\begin{aligned}
& \mathrm{N}=\sum 2 \lambda / \mathrm{D} 1(\mathrm{n} \pi / \mathrm{L})^{2}+\lambda\left[1-\phi\left(\mathrm{D} \mathrm{n}^{2} \pi^{2} / \mathrm{L}^{2}\right)\right] \\
& \text { and } \\
& \begin{aligned}
\tau 1= & -\mathrm{L} \mathrm{G}(0)^{\prime}=\mathrm{R}^{2} /(2 \mathrm{D})\left\{1 /\left(1-(\mathrm{b} / \mathrm{R})^{2}\right) \log (\mathrm{R} / \mathrm{b})\right. \\
& \left.+\left[1-(\mathrm{b} / \mathrm{R})^{2}\right] /(\mathrm{bk})\right\}-\mathrm{R}^{2} /(8 \mathrm{D})\left[3-(\mathrm{b} / \mathrm{R})^{2}\right] \\
\fallingdotseq & \mathrm{R}^{2} /(2 \mathrm{D})(\log (\mathrm{R} / \mathrm{b})+1 /(\mathrm{bk}))
\end{aligned}
\end{aligned}
$$
and

$$
\begin{aligned}
\tau 2= & -\phi(0)^{\prime}=R^{2} /(2 \mathrm{D})\left\{\log (\mathrm{a} / \mathrm{b})+\left[1-(\mathrm{b} / \mathrm{R})^{2}\right] /(\mathrm{bk})\right\} \\
& -\left(\mathrm{a}^{2}-\mathrm{b}^{2}\right) /(4 \mathrm{D})=\mathrm{R}^{2} /(2 \mathrm{D})(\log (\mathrm{a} / \mathrm{b})+1 /(\mathrm{bk})) \\
\tau 3= & 1 / \lambda \\
\tau= & 1 /(\text { no } 4 \pi \mathrm{DL})[\log (\mathrm{R} / \mathrm{b})+1 /(\mathrm{bk})+\mathrm{N}(\log (\mathrm{a} / \mathrm{b}) \\
& +1 /(\mathrm{bk}))+\mathrm{N} \text { no } 4 \pi \mathrm{DL} / \lambda]
\end{aligned}
$$

Then, th association rate $\mathrm{ka}$ is

$$
\begin{aligned}
\mathrm{ka}= & 4 \pi \mathrm{DL} /(\log (\mathrm{R} / \mathrm{b})+\mathrm{N} \log (\mathrm{a} / \mathrm{b}) \\
& +(\mathrm{N}+1) /(\mathrm{bk})+\mathrm{N} \text { no } 4 \pi \mathrm{DL} / \lambda)
\end{aligned}
$$

With the regular diffusion rate $\mathrm{D}=510^{-7} \mathrm{~cm}^{2} / \mathrm{s}$, the reaction radius $b=610^{-7} \mathrm{~cm}$, length of DNA $2 \mathrm{~L}=1.6$ $10^{-3} \mathrm{~cm}$, we can get

$\mathrm{ka}=1.210^{-11} \mathrm{~cm}^{3} / \mathrm{s}$ and equilibrium coefficient

$\mathrm{Kc}=1.4 \mu \mathrm{g} / \mathrm{cm}^{3}$

\section{APPENDIX 2.}

Refer to Carslaw Jager pp 222. XI.

\section{Theorem}

For the infinite hollow cylinder $\mathrm{a}<\mathrm{r}<\mathrm{b}, 0<\mathrm{z}<\mathrm{L}$. $\mathrm{r}=\mathrm{a}$ kept at temperature $f(z)$. Radiation at the other surfaces into medium at zero

$$
\begin{aligned}
& \quad \mathrm{v}=2 \sum(\alpha \mathrm{n} \cos (\alpha \mathrm{nz})+\mathrm{h} \sin (\alpha \mathrm{nz})) \phi(\mathrm{r} ; \mathrm{n}) \\
& \quad \int \mathrm{f}(\mathrm{z})(\alpha \mathrm{n} \cos (\alpha \mathrm{nz})+\mathrm{h} \sin (\alpha \mathrm{nz})) \mathrm{dz} \\
& /\left[\left(\alpha \mathrm{n}^{2}+\mathrm{h}^{2}\right) \mathrm{L}+2 \mathrm{~h}\right] \phi(\mathrm{a} ; \mathrm{n}) \\
& \text { where } \\
& \phi(\mathrm{r} ; \mathrm{n})=\operatorname{Io}(\mathrm{r} \alpha \mathrm{n})[\alpha \mathrm{nK} 1(\mathrm{~b} \alpha \mathrm{n})-\mathrm{hKo}(\mathrm{b} \alpha \mathrm{n})] \\
& \quad+\mathrm{Ko}(\mathrm{r} \alpha \mathrm{n})[\alpha \mathrm{nI}(\mathrm{b} \alpha \mathrm{n})+\mathrm{h} \operatorname{Io}(\mathrm{b} \alpha \mathrm{n})]
\end{aligned}
$$

Proof

The basic differential equation of this system is $\partial^{2} \mathrm{v} / \partial \mathrm{r}^{2}+1 / \mathrm{r} \partial \mathrm{v} / \partial \mathrm{r}=\mathrm{k} \partial^{2} \mathrm{v} / \partial \mathrm{z}^{2}$ 
The boundary conditions are

$\mathrm{v}=\mathrm{f}(\mathrm{z})$ at $\mathrm{r}=\mathrm{a}$

$$
\begin{array}{rr}
\partial v / \partial r+h v=0 & \text { at } r=b \\
-\partial v / \partial z+h v=0 & \text { at } z=0 \\
\partial v / \partial z+h v=0 & \text { at } z=L
\end{array}
$$

The general form of the solution is

$\mathrm{v}=\Sigma[\operatorname{An} \operatorname{Io}(\mathrm{r} \alpha \mathrm{n})+\operatorname{Bn} \operatorname{Ko}(\mathrm{r} \alpha \mathrm{n})][\mathrm{Cn} \cos (\alpha \mathrm{nz})$

+ Dn $\sin (\alpha \mathrm{nz})]$.

Putting $\mathrm{Cn} / \mathrm{Dn}=\alpha \mathrm{n} / \mathrm{h}$,

$\mathrm{v}=\Sigma[\operatorname{An} \mathrm{Io}(\mathrm{r} \alpha \mathrm{n})+\operatorname{Bn} \mathrm{Ko}(\mathrm{r} \alpha \mathrm{n})] \mathrm{Cn}[\cos (\alpha \mathrm{nz})$

$+\mathrm{h} / \alpha \mathrm{n} \sin (\alpha \mathrm{nz})]$.

Setting $\mathrm{An}=\mathrm{An} \mathrm{Cn}, \mathrm{Bn}=\mathrm{BnCn}$ and

$\mathrm{Xn}=\cos (\alpha \mathrm{nz})+\mathrm{h} / \alpha \mathrm{n} \sin (\alpha \mathrm{nz})$

we have

$v=\sum X n[\operatorname{An} \operatorname{Io}(r \alpha n)+\operatorname{Bn} \operatorname{Ko}(r \alpha n)]$

From the boundary condition (2) at $r=b$,

$\partial \mathrm{v} / \partial \mathrm{t}=\mathrm{Xn}[\mathrm{An} \alpha \mathrm{nI} 1(\mathrm{r} \alpha \mathrm{n})-\mathrm{Bn} \alpha \mathrm{n} \mathrm{K1}(\mathrm{r} \alpha \mathrm{n})]$

Thus, we have

An $\alpha \mathrm{nI}(\mathrm{b} \alpha \mathrm{n})-\mathrm{Bn} \alpha \mathrm{n} \mathrm{K1}(\mathrm{b} \alpha \mathrm{n})+\mathrm{h}[\mathrm{An} \operatorname{Io}(\mathrm{b} \alpha \mathrm{n})$

This is

$$
+\operatorname{Bn} \operatorname{Ko}(b \alpha n)]=0 \text {. }
$$

An $[\alpha \mathrm{nI}(\mathrm{b} \alpha \mathrm{n})+\mathrm{h}$ An Io(b $\alpha \mathrm{n})]=\mathrm{Bn}[\alpha \mathrm{n} \mathrm{K1}(\mathrm{b} \alpha \mathrm{n})$

$-\mathrm{h} \mathrm{Ko}(\mathrm{b} \alpha \mathrm{n})]$.

For the simple, we express this by

An $\mathrm{C} 1=\mathrm{Bn} C 2$.

Substituting $\mathrm{Bn}=\mathrm{An} \mathrm{C} 1 / \mathrm{C} 2$ to $\mathrm{v}$ $v=\sum X n A n / C 2[C 2 \operatorname{Io}(\mathrm{r} \alpha n)+C 1 \operatorname{Ko}(\mathrm{r} \alpha \mathrm{n})]$

Putting

$\mathrm{C} 2 \mathrm{Io}(\mathrm{r} \alpha \mathrm{n})+\mathrm{C} 1 \mathrm{Ko}(\mathrm{r} \alpha \mathrm{n})$

$=[\alpha \mathrm{nK} 1(\mathrm{~b} \alpha \mathrm{n})-\mathrm{h} \mathrm{Ko}(\mathrm{b} \alpha \mathrm{n})] \operatorname{Io}(\mathrm{r} \alpha \mathrm{n})$

$+\operatorname{Ko}(\mathrm{r} \alpha \mathrm{n})[\alpha \mathrm{nI}(\mathrm{b} \alpha \mathrm{n})+\mathrm{h} \operatorname{Io}(\mathrm{b} \alpha \mathrm{n})]=\phi(\mathrm{r} ; \mathrm{n})$.

Then we have

$v=\sum X n$ An $\phi(r ; n) / C 2$.

Applying the boundary condition

we have

$$
\mathrm{v}=\mathrm{f}(\mathrm{z}) \text { at } \mathrm{r}=\mathrm{a} \text {, }
$$

$\mathrm{f}(\mathrm{z})=\sum \mathrm{Xn}$ An $\phi(\mathrm{a} ; \mathrm{n}) / \mathrm{C} 2$.

Multiplying $\mathrm{Xm}(\mathrm{z})$ on both side of this and integrate

for the range $[0, L]$,

we have

$\int \mathrm{f}(\mathrm{z}) \mathrm{Xm}(\mathrm{z}) \mathrm{dz}=\Sigma$ An $\phi(\mathrm{a} ; \mathrm{n}) / \mathrm{C} 2 \quad \int \mathrm{Xn} \mathrm{Xm} \mathrm{dz}$

The right side of the equation is effective only for $m=n$ $\int \mathrm{Xn}^{2} \mathrm{dz}=\left[\left(\alpha \mathrm{m}^{2}+\mathrm{h}^{2}\right) \mathrm{L}+2 \mathrm{~h}\right] /\left(2 \alpha \mathrm{m}^{2}\right)$

Therefore

$\int \mathrm{f}(\mathrm{z}) \mathrm{Xm}(\mathrm{z}) \mathrm{dz}=\mathrm{An} \phi(\mathrm{a} ; \mathrm{n}) / \mathrm{C} 2$

Thus, we have

$$
*\left[\left(\alpha m^{2}+h^{2}\right) L+2 h\right] /\left(2 \alpha m^{2}\right) \text {. }
$$

$$
A n=2 \alpha n^{2} C 2 /\left\{\left[\left(\alpha n^{2}+h^{2}\right) L+2 h\right]^{*} \phi(a ; n)\right\}
$$$$
\int \mathrm{f}(\mathrm{z}) \mathrm{Xn}(\mathrm{z}) \mathrm{dz}
$$

$\mathrm{Bn}=2 \alpha \mathrm{n}^{2} \mathrm{C} 1 /\left\{\left[\left(\alpha \mathrm{n}^{2}+\mathrm{h}^{2}\right) \mathrm{L}+2 \mathrm{~h}\right]^{*} \phi(\mathrm{a} ; \mathrm{n})\right\}$

$$
\int f(z) \operatorname{Xn}(z) d z
$$

Therefore

$\mathrm{v}=\sum \mathrm{Xn}[\mathrm{An} \operatorname{Io}(\mathrm{r} \alpha \mathrm{n})+\operatorname{Bn} \mathrm{Ko}(\mathrm{r} \alpha \mathrm{n})]$

$=2 \sum \alpha \mathrm{n}^{2} \mathrm{Xn} *[\mathrm{C} 2 \operatorname{Io}(\mathrm{r} \alpha \mathrm{n})+\mathrm{C} 1 \operatorname{Ko}(\mathrm{r} \alpha \mathrm{n})]$

$/\left\{\left[\left(\alpha n^{2}+h^{2}\right) L+2 h\right]^{*} \phi(a ; n)\right\} \int f(z) X n(z) d z$

Consequently, we have A1 in APPENDIX 3.

\section{APPENDIX 3.}

We show the precise mathematical process for obtaining the $\mathrm{r}$ dependent part of the solution.
For $\mathrm{r}<\mathrm{a}$

$w(r, s)=\left[I_{1}(q R) K_{0}(q a)+K_{1}(q R) I_{0}(q a)\right] /\left\{2 \pi D I_{1}(q R)\right.$

[ $\left.\mathrm{kK}_{0}(\mathrm{qb})+\mathrm{q} \mathrm{K}_{1}(\mathrm{qb})\right]+\mathrm{K}_{1}(\mathrm{qR})\left[\mathrm{k} \mathrm{Io}_{(\mathrm{qb})}-\mathrm{q} \mathrm{I}_{1}(\mathrm{qb})\right]$

$*\left\{\left[\mathrm{k} \mathrm{K} \mathrm{K}_{0}(\mathrm{qb})+\mathrm{q} \mathrm{K} \mathrm{K}_{1}(\mathrm{qb})\right] \mathrm{I}_{0}(\mathrm{qr})\right.$

- $[\mathrm{kI} \operatorname{lo}(\mathrm{qb})-\mathrm{qI} 1(\mathrm{qb})] \mathrm{Ko}(\mathrm{qr})\} \quad(\mathrm{q}=\sqrt{\mathrm{s} / \mathrm{D}})$

From the equation (A-3), the $z$-independent flux $\psi(t)$ of particles onto the chain. Its Laplace transform is

$$
\begin{aligned}
& \phi(s)=2 \pi b D \stackrel{\partial w}{\partial r(r=b)}\left\{\begin{array}{l}
{\left[I_{1}(q R) K_{0}(q a)+K_{1}(q R) I_{0}(q a)\right]} \\
\left.-k K_{0}(q b)+q K_{1}(q b)\right]
\end{array}\right. \\
& \left.+\mathrm{K}_{1}(\mathrm{qR})\left[\mathrm{k} \mathrm{I}_{0}(\mathrm{qb})-\mathrm{q} \mathrm{I}_{1}(\mathrm{qb})\right]\right\}
\end{aligned}
$$

The $z$ - dependent flux in the equation (12) is equal to

$$
\mathrm{F}\left(\mathrm{z}, \mathrm{z}^{\prime}, \mathrm{t}\right)=\psi(\mathrm{t}) \quad \mathrm{v}(\mathrm{z}, \mathrm{t})
$$

Hence the Laplace transform of $F$ is

$$
\begin{gathered}
F\left(z, z^{\prime}, s\right)=\phi(s) / L+2 / L \sum_{n=1}^{\infty} \phi\left(s+D(n \pi / L)^{2}\right) \\
\cos \left(n \pi z^{\prime} / L\right) \cos (n \pi z / L)
\end{gathered}
$$

The Laplace transform of flux $G(z, s)$ is calculated through the integration $F\left(z, z^{\prime}, s\right)$.

$\mathrm{G}(\mathrm{s})=2 \mathrm{~b} k\left[\mathrm{I}_{1}(\mathrm{qR}) \mathrm{K}_{1}(\mathrm{qb})-\mathrm{K}_{1}(\mathrm{qR}) \mathrm{I}_{1}(\mathrm{qb})\right] /\left\{\mathrm{I}_{1}(\mathrm{qR})\right.$

$\left[\mathrm{k} \mathrm{K}_{0}(\mathrm{qb})+\mathrm{q} \mathrm{K}_{1}(\mathrm{qb})\right]+\mathrm{K}_{1}(\mathrm{qR})\left[\mathrm{kI}(\mathrm{qb})-\mathrm{q} \mathrm{I}_{1}(\mathrm{qb})\right]$

$\left.L\left(R^{2}-b^{2}\right) q\right\}$

The original differential equation is, then transformed as

$$
\text { D1 } \begin{gathered}
\partial^{2} u / \partial z^{2}-s u-\lambda u+\lambda \int d z^{\prime} F\left(z, z^{\prime}, s\right) u\left(z^{\prime}, s\right) \\
+G(s)=0
\end{gathered}
$$

With the boundary conditions

$$
\mathrm{u}(0, \mathrm{~s})=0, \quad \partial \mathrm{u} / \partial \mathrm{z}(\mathrm{z}=\mathrm{L})=0, \quad \text {-.-.-A7 }
$$

The flux of particles into the sink

$$
\Phi(\mathrm{s})=\mathrm{D} 1 \quad \partial \mathrm{u} / \partial \mathrm{z}(\mathrm{z}=0)
$$

is obtained by solving A- 6 and A-7. The solution satisfying the boundary conditions $\mathrm{A} 7$ is

$$
u(z, s)=\sum_{n=0}^{\infty o} f n(s) \sin [(2 n+1) \pi z /(2 L)]
$$

Entering this and the expression $\mathrm{A} 4$ into equation $\mathrm{A} 6$

$$
\begin{aligned}
& \pi^{2} \\
& -\sum_{n=0}\left(D 1 \frac{\pi^{2}}{-\cdots}(2 n+1)^{2}+s+\lambda\right) f n(s) \sin -(2 n+1) \pi z
\end{aligned}
$$



where we have defined

$$
\begin{array}{rlrl}
\operatorname{gm}(\mathrm{s}) & =\phi(\mathrm{s}) / \mathrm{L} & \mathrm{m}=0 & \\
& =2 / \mathrm{L} \phi\left(\mathrm{s}+\mathrm{D} \mathrm{m} \mathrm{m}^{2} \pi^{2} \mathrm{~L}^{2}\right) & \mathrm{m}>0 & --\mathrm{A} 11
\end{array}
$$

Multiplying $A 6$ by $\cos \left(\mathrm{m}^{\prime} \pi \mathrm{z} / \mathrm{L}\right)$ and integrating from $\mathrm{z}=0$ to $\mathrm{z}+\mathrm{l}$. Partial integration over $\partial^{2} \mathrm{u} / \partial \mathrm{z}^{2}$ before entering the expression $\mathrm{A} 9$ and $\mathrm{A} 4$ and then, completing the integration. Multiplying A10 by $\sin \left[\left(2 n^{\prime}+1\right) \pi z /(2 L)\right.$ ] and integrating from $\mathrm{z}=0$ to $\mathrm{z}=\mathrm{L}$ gives another relation containing this sum. 


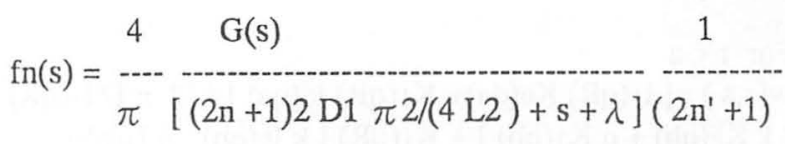

$$
\begin{aligned}
& 4(\pi \mathrm{D} 1 /(2 \mathrm{~L}) \Sigma(2 \mathrm{n}+1) \mathrm{fn}(\mathrm{s})-\mathrm{LG}(\mathrm{s}) \delta \mathrm{mo}
\end{aligned}
$$

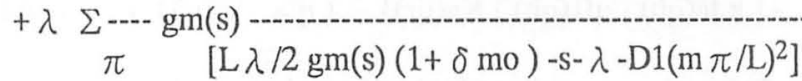

$$
\begin{aligned}
& \text { * }\left(2 n^{\prime}+1\right) /\left[\left(2 n^{\prime}+1\right)^{2}-4 m^{2}\right] * \\
& {\left[\left(2 n^{\prime}+1\right)^{2} D 1 \pi^{2} /\left(4 L^{2}+s \lambda\right)\right]}
\end{aligned}
$$

Multiplying $A-12$ by $2 n^{\prime}+1$ and summing $n^{\prime}$ from zero to infinity, we can solve for $\Sigma(2 n+1) f n(s)$

$$
\begin{aligned}
\Phi(\mathrm{s}) & =\mathrm{D} 1 \partial \mathrm{u} / \partial \mathrm{z}(\mathrm{z}=0) \\
& =\mathrm{D} 1 \pi /(2 \mathrm{~L}) \Sigma(2 \mathrm{n}+1) \mathrm{fn}(\mathrm{s})
\end{aligned}
$$

We reach the equation 3-17.

\section{APPENDIX 4}

\section{Seeking $G(s)$, since}

$$
\begin{aligned}
\mathrm{qb} & =\mathrm{b}^{*} \operatorname{sqr}(\mathrm{s} / \mathrm{d})=\mathrm{b}^{*} 10^{-7} \operatorname{sqr}(\mathrm{s}) /\left(5^{*} 10^{-7}\right)^{1 / 2} \\
& =\operatorname{sqr}(\mathrm{s}) * 2.68 * 10^{-3.5} \\
\mathrm{qR} & =\mathrm{R}^{*} \operatorname{sqr}(\mathrm{s} / \mathrm{d})=\mathrm{b}^{*} 10^{-5} \operatorname{sqr}(\mathrm{s}) /\left(5^{*} 10^{-7}\right)^{1 / 2} \\
& =\operatorname{sqr}(\mathrm{s}) * 2.68 * 10^{-1.5}
\end{aligned}
$$

we can apply the Allen's approximation for the Bessel functions $\mathrm{I}_{0}(\mathrm{qb}), \mathrm{I}_{1}(\mathrm{qR}), \mathrm{K}_{0}(\mathrm{qb}), \mathrm{K}_{1}(\mathrm{qb}), \mathrm{K}_{1}(\mathrm{qR})$ and $\mathrm{I}_{1}(\mathrm{qb})$.

to satisfy $x \leqq 3.75$

$$
\begin{array}{cc}
\operatorname{sqr}(\mathrm{s}) * 2.68 * 10^{-3.5} \leqq 3.75 & \text { Hence } \\
\mathrm{s} \leqq 10^{7}(3.75 / 2.68)^{2} & \\
\mathrm{sqr}(\mathrm{s}) * 2.68 * 10^{-1.5} \leqq 3.75 & \text { Hence } \\
\mathrm{s} \leqq 10^{3}(3.75 / 2.68)^{2} &
\end{array}
$$

Thus, we have following approximation forms for sufficently large s ( short time domain)

1) $\operatorname{Io}(q b)=\sum_{k=0} a k(q b / 3.75)^{2 k}=\sum_{k=0} a k q^{2 k}$

$$
6 \quad 6
$$

2) $I_{1}(q b)=q b \sum a_{k}(q b / 3.75)^{2 k}=\sum b_{k} q^{2 k+1}$ $\mathrm{k}=0 \quad \mathrm{k}=0$

3) $\mathrm{K}_{0}(\mathrm{qb})=-\log ((\mathrm{qb}) / 2)^{*} \mathrm{IO}(\mathrm{qb})+\sum \mathrm{ak}(\mathrm{qb} / 2)^{2 \mathrm{k}}$

$$
\mathrm{k}=0
$$

$$
=-\log ((q b) / 2)^{*} \operatorname{IO}(q b)+\sum_{k=0} c k q^{2 k}
$$

5) $\mathrm{K} 1(\mathrm{qb})=\log ((q b) / 2) * I 1(q b)+\sum a k(q b / 2)^{2 k} / b$

$$
=\log ((q b) / 2)^{*} 11(q b)+\sum_{k=0} d_{k} q^{2 k-1}
$$

$$
\begin{aligned}
& \text { 7) Denominator of } G(s) / q \text { is } \\
& =\mathrm{I} 1(\mathrm{qR})[\mathrm{k} \mathrm{K0}(\mathrm{qb})+\mathrm{q} \mathrm{K} 1(\mathrm{qb})]+\mathrm{K} 1(\mathrm{qR})[\mathrm{kIO}(\mathrm{qb})-\mathrm{q} \mathrm{I} 1(\mathrm{qb})] \\
& =\mathrm{I} 1(\mathrm{qR})\left[\mathrm{k}\left(-\log ((\mathrm{qb}) / 2) * \mathrm{IO}(\mathrm{qb})+\sum \mathrm{ck} \mathrm{q}^{2 \mathrm{k}}\right)\right. \\
& \left.+\mathrm{q}\left(\log ((\mathrm{qb}) / 2) * \mathrm{I} 1(\mathrm{qb})+\sum \mathrm{d}_{\mathrm{k}} \mathrm{q}^{2 \mathrm{k}-1}\right)\right] \\
& +\left(\log ((\mathrm{qR}) / 2)^{*} \mathrm{I} 1(\mathrm{qR})+\sum \mathrm{ek}_{\mathrm{q}} \mathrm{q}^{2 \mathrm{k}-1}\right)[\mathrm{k} \mathrm{IO}(\mathrm{qb})-\mathrm{q} \mathrm{I} 1(\mathrm{qb})] \\
& =\log (q b / 2) I 1(q R)[-k I 0(q b)+q I 1(q b)] \\
& +\log (q R / 2) \text { I1(qR) [k IO(qb) - q I1(qb) ] } \\
& +\mathrm{k} I 1(\mathrm{qR}) \Sigma \mathrm{ck} \mathrm{q}^{2 \mathrm{k}}+\mathrm{I} 1(\mathrm{qR}) \Sigma \mathrm{d}_{\mathrm{k}} \mathrm{q}^{2 \mathrm{k}} \\
& +\mathrm{kIO}(\mathrm{qb}) \sum \mathrm{e}_{\mathrm{k}} \mathrm{q}^{2 \mathrm{k}-1}-\mathrm{I}(\mathrm{qb}) \sum \mathrm{e}_{\mathrm{k}} \mathrm{q}^{2 \mathrm{k}}
\end{aligned}
$$

The first and the second terms are $=-\log (\mathrm{b} / \mathrm{R}) \operatorname{I}(\mathrm{qR})[\mathrm{kIO}(\mathrm{qb})-\mathrm{q} \operatorname{I}(\mathrm{qb})]$

The third and the fourth terms are

$=\mathrm{I} 1(\mathrm{qR})\left[\mathrm{k} \quad \sum \mathrm{ck} \mathrm{q}^{2 \mathrm{k}}+\sum \mathrm{dk} \mathrm{q}^{2 \mathrm{k}}\right]$

setting $\quad \Sigma(\mathrm{kcL}+\mathrm{dL})=\sum \mathrm{hL}=\mathrm{I} 1(\mathrm{qR}) \quad \sum \mathrm{hm} \mathrm{q} \mathrm{q}^{2 \mathrm{~m}}$

$$
\mathrm{L}=0 \quad \mathrm{~L}=0 \quad \mathrm{~m}=0
$$

Hence, the denominator is

$=\mathrm{q}[-\log (\mathrm{b} / \mathrm{R}) \mathrm{I} 1(\mathrm{qR})[\mathrm{k} \mathrm{l}(\mathrm{q} \mathrm{q})-\mathrm{q}$ I1 $(\mathrm{qb})]$

$+\mathrm{I} 1(\mathrm{qR}) \quad \sum \mathrm{hm} \mathrm{q^{2m }}$

$+[\mathrm{k} I 0(\mathrm{qb})-\mathrm{q} I 1(\mathrm{qb})] \sum \mathrm{ck} \mathrm{q}^{2 \mathrm{k}-1}$

These are even functions because $\mathrm{q}$ is multiplied from

\begin{tabular}{|c|c|c|c|}
\hline 7 & 6 & 7 & 6 \\
\hline$=\sum V_{n=0} q^{2 n}$ & $\sum_{k=0} B q^{2 k+2}$ & $\sum_{n=0} U_{n} q^{2 n}$ & $\sum \mathrm{ck}_{\mathrm{k}} \mathrm{q}^{2 \mathrm{k}}$ \\
\hline
\end{tabular}
the out side.

$\% \% \% \% \% \% \% \% \% \% \% \% \% \% \% \% \% \% \% \% \% \% \% \% \% \% \% \%$

\section{Denominator}

$=-\log (\mathrm{b} / \mathrm{R}) \mathrm{q} \mathrm{I} 1(\mathrm{qR})$ [ k I0(qb) - q I1(qb) ]

$+q I 1(q R) \sum h m q^{2 m}+q[k I 0(q b)-q I 1(q b)] \sum e_{k} q^{2 k-1}$ $\mathrm{m}=0$

$=-\log (\mathrm{b} / \mathrm{R}) \sum \mathrm{B}_{\mathrm{k}} \mathrm{q}^{2 \mathrm{k}+2}\left[\mathrm{k}\right.$ IO(qb) $\left.-\sum b_{k} \mathrm{q}^{2 \mathrm{k}+2}\right]$

$+\sum B k q^{2 k+2} \sum h m q^{2 m}$

$+\left[k I 0(q b)-\sum b k q^{2 k+2}\right] \sum e_{k} q^{2 k}$

On the other hand

$k \mathrm{IO}(\mathrm{qb})-\sum \mathrm{bk} \mathrm{q}^{2 \mathrm{k}+2}$

$$
k=0
$$

$=\sum_{\mathrm{L}=0} \mathrm{aLq}^{2 \mathrm{~L}}-\sum_{\mathrm{L}=0} \mathrm{bL} \mathrm{q}^{2 \mathrm{~L}+2}=\sum_{\mathrm{n}=0} \mathrm{Un} \mathrm{q}^{2 \mathrm{n}}$

Then, 7

Deominator $=-\underset{k=0}{\log (b / R) \sum B_{k}} q_{n=0}^{2 k+2} \sum U n q^{2 n}$

$+\sum B k q^{2 k+2} \sum h m q^{2 m}+\sum U n q^{2 n} \sum e_{k} q^{2 k}$ $\mathrm{k}=0 \quad \mathrm{~m}=0 \quad \mathrm{n}=0 \quad \mathrm{k}=0$

$=\left[-\log (\mathrm{b} / \mathrm{R}) \sum U n \mathrm{q}^{2 \mathrm{n}}+\sum h m \mathrm{q}^{2 \mathrm{~m}}\right] \sum B \mathrm{k} \mathrm{q}^{2 \mathrm{k}+2}$

$+\sum_{n=0} U_{n} q^{2 n} \sum_{k=0}^{n e 0} e_{k} q^{2 k}$

The first term can be 7

$-\log (\mathrm{b} / \mathrm{R}) \sum U n \mathrm{q}^{2 \mathrm{n}}=\sum V n \mathrm{q}^{2 \mathrm{n}}$ $\mathrm{n}=0$

The denominator

can be also expressed in finite series of $\mathrm{q}$.

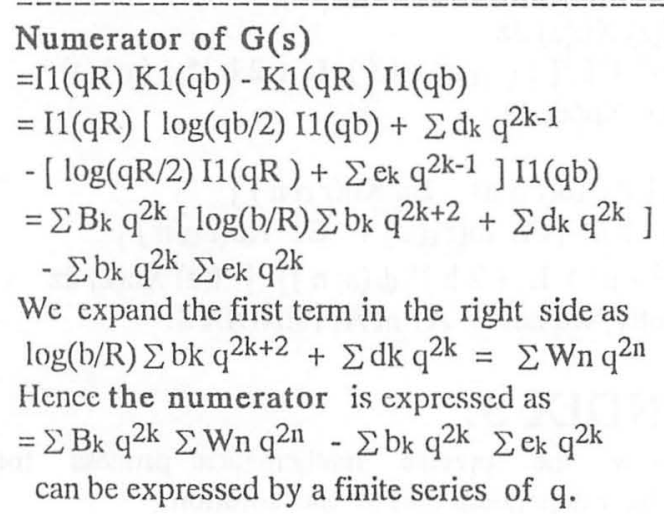

